\title{
DISTRIBUTION OF WHEAT PROTEIN COMPONENTS UNDER DIFFERENT GENETIC BACKGROUNDS AND ENVIRONMENTS
}

\author{
Daniela HORVAT ${ }^{1 *}$, Georg DREZNER ${ }^{l}$, Rezica SUDAR ${ }^{l}$, Gordana ŠIMIĆ , \\ Krešimir DVOJKOVIĆ ${ }^{\text {, Valentina ŠPANIĆ }}$, Damir MAGDIĆ ${ }^{1}$ \\ ${ }^{1}$ Agricultural Institute Osijek, Juzno predgradje 17, Osijek, CROATIA \\ ${ }^{2}$ Faculty of Food Technology Osijek, Franje Kuhaca 20, Osijek, CROATIA \\ *Corresponding author: daniela.horvat@poljinos.hr
}

Received: 11.07 .2014

\begin{abstract}
The crude protein and protein components of fourteen commercial bread wheat cultivars grown in Eastern Croatia over two years and three locations were evaluated. Protein components were measured by reversed phase - high pressure liquid chromatography. A dominant effect of genotypes was obtained for the proportion of albumins and globulins, $\gamma$ - gliadins and total glutenins, while year had a more pronounced impact on crude protein, total gliadins and high molecular weights and low molecular weights glutenin subunits. Locations had the strongest influence on total extracted proteins. Variability of gliadins to glutenins ratio was at the same extent influenced by the genotype and the year. Among interactions, genotype $\mathbf{x}$ year and year $\mathbf{x}$ location had the highest impact on evaluated proteins. The principal component analysis showed that wheat cultivars were differentiated according to variability of grain protein components. Considering the significant impact of proteins on the wheat bread-making quality, cultivar classification by protein components significantly contributes to the improvement of breeding program towards the creation of high quality cultivars.
\end{abstract}

Keywords: wheat, protein components, environments, RP-HPLC

\section{INTRODUCTION}

Wheat (Triticum aestivum L.) proteins are closely related to nutritional and bread-making quality of wheat. Wheat grains contain $8-20 \%$ proteins which are traditionally divided into four major classes: the watersoluble albumins, the salt-soluble globulins, the alcohol soluble gliadins and the glutenins which are in dilute acid or alkali (Wieser and Kieffer, 2001). The wheat proteins content and composition are strongly influenced by genetic background and in the evaluation of bread-making quality the composition of polymeric high molecular weight-glutenin subunits (HMW) and low molecular weight- glutenin subunits (LMW) are of particular importance. These glutenin (GLU) components together with $\omega$-, $\alpha$ - and $\gamma$ - gliadins (GLI) are the major storage proteins of endosperm and form a complex called gluten which is responsible for dough elasticity and extensibility as an important rheological characteristics of food based on wheat. Gluten constitutes 78-85 \% of total wheat proteins. It is well established that flour with higher gluten strength contains favourable HMW (1 and 2 at the Glu-1 locus, $7+8$ at the Glu-B1 locus and $5+10$ at the Glu-D1 locus) or a greater amount of total glutenins or certain glutenin components (Shewry et al., 2001; Pena et al., 2005; Horvat et al., 2013). Albumins and globulins (AG) constitute $10-22 \%$ of total flour protein. These proteins are mainly present in the aleuronic layer and embryo and include many enzymes and regulatory proteins. While the influence of gluten proteins on bread-making quality of wheat is extensively studied, a smaller number of studies dealing with the influence of AG as non-gluten proteins on wheat quality (Gao et al., 2009; Osipova et al., 2012).

Environmental conditions such as nitrogen, soil type, water access and temperature during growth, especially through the grain filling period, had a significant influence on wheat quality through its impact on relative content of total and specific protein components and consequently on their ratios (Dupont and Altenbach, 2003; Torbica et al., 2007; Haiying et al., 2012; Erekul et al., 2012). The negative influence of higher gliadins to glutenins ratio (GLI/GLU) on dough rheological properties is well established and also confirmed in papers published recently (Tang et al., 2008; Anderson et al., 2011; Horvat et al. 2013).

The objective of this study was to assess how distribution of protein components in whole meal of wheat varies across different genetic backgrounds and growth environments. The obtained results may contribute to the development of new cultivars with improved breadmaking quality. 


\section{MATERIALS AND METHODS}

\section{Genetic material}

Fourteen wheat cultivars were grown during two growing seasons $(2008 / 2009,2009 / 2010)$ at three different regions in the Eastern Croatia that present a different types of soil (Osijek-eutric cambisol, $\mathrm{pH}(\mathrm{KCl})$ around 6.00 , humus $=2.0 \%-2.20 \%$; Tovarnik-black earth, $\mathrm{pH}(\mathrm{KCl})$ above 7.00, humus $=2.75 \%-3.00 \%$ and Pozegapseudogley, $\mathrm{pH}(\mathrm{KCl})$ below 5.00, humus $=1.60 \%$ $1.80 \%)$. French cultivar Soissons is well distributed at Croatian wheat market (Table 1). Genotypes were sown in eight row plots of $7.0 \mathrm{~m}$ length and $1.08 \mathrm{~m}$ wide in October with a sowing rate of 330 seeds $\mathrm{m}^{-2}$. The experimental layout was a Randomized Complete Block Design with four replications. The applied agrotechnical measures were standard in the cultivated area. The climatical conditions during the growing season significantly differed in the amount of rainfall and average temperatures at different locations and years (2008/09: Osijek $=368.6 \mathrm{~mm}, 10.8{ }^{\circ} \mathrm{C}$; Pozega $=528.1 \mathrm{~mm}, 10.2$ ${ }^{\circ} \mathrm{C}$; Tovarnik $=430.6 \mathrm{~mm}, 11.2{ }^{\circ} \mathrm{C}$; 2009/10: Osijek $=$ $846.0 \mathrm{~mm}, 10.3^{\circ} \mathrm{C}$; Pozega $=829.5 \mathrm{~mm}, 9.9^{\circ} \mathrm{C}$; Tovarnik $=759.3 \mathrm{~mm}, 10.7^{\circ} \mathrm{C}$ ).

Table 1. Bread wheat cultivars, their origin of registration and pedigrees used in the study

\begin{tabular}{lll}
\hline Genotype & Origin & Pedigree \\
\hline Srpanjka & PIO , CRO, 1989 & Osk.4.50-1-77/Zg 2696 \\
Žitarka & PIO, CRO, 1985 & Osk.6.30-20/Slavonka/3/Eph M68/Osk.154-19//Kavkaz \\
Divana & JS, CRO,1996 & Favorit/5/Cirpiz/4/Jang/Kwang/2/Atlass 66/Comanche/3/Velvet \\
Aida & PIO, CRO, 2006 & Srpanjka/Rialto \\
Felix & PIO, CRO, 2007 & Srpanjka/K160-86 \\
Zlata & PIO, CRO, 2007 & Ana/Osk.4.48-1-91 \\
Ilirija & PIO, CRO, 2008 & Osk.14.294-16-95/Soissons \\
Sana & Bc, CRO, 1983 & Mura/CI14123//Zg2413-72 \\
Seka & PIO, CRO,2006 & Srpanjka/Demetra \\
Renata & PIO, CRO,2006 & Zitarka/Osk.7.5-4-82/KB160/86//Srpanjka \\
Golubica & PIO, CRO,1998 & Slavonija/Gemini \\
Soissons & FD, FRA, 1987 & Lena/HN35 \\
Olimpija & PIO, CRO, 2009 & Slavonija/KH-1/98 \\
Vulkan & PIO, CRO, 2009 & Osk.3.343-1-97/FS-811-98//KRH-44-99 \\
\hline aIO - Agricultural Institute Osijek, Croatia; Bc - Bc Institute, Zagreb, Croatia; JS - Jost-Seed, Križevci, Croatia; FD - Florimond Desprez, France
\end{tabular}

\section{Determination of wheat grain proteins}

The crude protein $(\mathrm{P})$ content of grains $(\mathrm{N}$ x 5.7, DM) was measured by the NIT technology (Infratec 1241, Foss Tecator). Prior the reversed phase - high pressure liquid chromatography (RP-HPLC) analysis, the protein components were extracted from $100 \mathrm{mg}$ of whole-wheat flour accordingly to the stepwise procedure of Wieser et al. (1998). Proteins were separated by Perkin Elmer LC 200 chromatograph on a Discovery Bio Wide Pore C18 column (300 ̊ pore size, $5 \mu \mathrm{m}$ particle size, $4.6 \mathrm{~mm} \times$ $150 \mathrm{~mm}$ i.d.) (Sigma-Aldrich Chemie GmbH, Germany). The instrument was controlled by Total-Chrom software (Perkin Elmer Instruments, USA). As mobile phase $0.1 \%$ trifluoroacetic acid (TFA) in water (v/v) and $0.1 \%$ TFA in acetonitrile $(\mathrm{ACN})(\mathrm{v} / \mathrm{v})$ were used. AG, GLI and GLU components were eluted with a linear gradient of ACN in range $24 \%-58 \%$ over $30 \mathrm{~min}$. The flow was $1 \mathrm{ml} / \mathrm{min}$ and column temperature was maintained at $50{ }^{\circ} \mathrm{C}$. All determinations were made in duplicate. The repeatability of the extraction procedure and RP-HPLC analysis should be within $\pm 5 \%$. The results have been expressed as $\%$ of total extracted protein (TEP) (relating the area under particular protein fraction to the summed area under AG, GLI and GLU chromatograms).

\section{Data analysis}

Data were processed by analysis of variance (ANOVA, $\mathrm{P}<0.05$ ), least significant difference (LSD) test and linear correlation analysis. A principal component analysis (PCA) was performed on the protein components data with aim to define similarities among cultivars. Statistical analysis was performed using Statistica (StatSoft Inc., USA) software ver. 8.0.

\section{RESULTS AND DISCUSSION}

A dominant effect (over $50 \%$ of the total variability) of genotypes $(\mathrm{G})$ was found for the proportion of $\mathrm{AG}$, and $\gamma$ - GLI and total GLU, while year (Y) had a more pronounced impact on P, total GLI, HMW and LMW. Variability of GLI/GLU ratio was the same extent influenced by $G$ and $Y$. Locations (L) had the strongest influence on TEP. Among interactions, G x Y and Y x L had the highest impact on evaluated protein components (Table 2). Regarding to quantitative results of proteins obtained by the RP-HPLC method specific differences among cultivars, years and locations were noticed (Table $3)$. 
Table 2. Analysis of variance (mean square values) for wheat protein components

\begin{tabular}{|c|c|c|c|c|c|c|c|c|c|c|c|c|}
\hline \multirow[b]{2}{*}{$\begin{array}{l}\text { Source of } \\
\text { variation }\end{array}$} & \multirow[b]{2}{*}{ df } & \multirow[b]{2}{*}{$\mathbf{P}^{\mathbf{a}}$} & \multirow[b]{2}{*}{ TEP } & \multirow[b]{2}{*}{$\mathbf{A G}$} & \multicolumn{4}{|c|}{ GLI } & \multicolumn{3}{|c|}{ GLU } & \multirow{2}{*}{$\begin{array}{l}\text { GLI/ } \\
\text { GLU }\end{array}$} \\
\hline & & & & & Total & $\omega-$ & $\alpha-$ & $\gamma-$ & Total & HMW & LMW & \\
\hline Genotype (G) & 13 & $15.5^{*}$ & $98783^{*}$ & $61.6^{*}$ & $99.8 *$ & $7.9 *$ & $76.9 *$ & $76.1^{*}$ & $82.3 *$ & $13.6^{*}$ & $55.6^{*}$ & $0.53 *$ \\
\hline Year $(\mathrm{Y})$ & 1 & $74.0 *$ & $211403^{*}$ & $27.4 *$ & $143.5^{*}$ & $1.9 *$ & $30.9 *$ & $26.8^{*}$ & $45.5^{*}$ & $22.3 *$ & $132.5^{*}$ & $0.48 *$ \\
\hline Location (L) & 2 & $49.3 *$ & $331557 *$ & $16.3 *$ & $29.5^{*}$ & $7.6^{*}$ & $51.4^{*}$ & $28.7 *$ & $4.6^{*}$ & $6.5^{*}$ & $8.1 *$ & $0.05 *$ \\
\hline $\mathrm{G}^{*} \mathrm{Y}$ & 13 & $1.0^{*}$ & $10810^{*}$ & $14.1 *$ & $23.9^{*}$ & $1.3^{*}$ & $10.6^{*}$ & $5.0^{*}$ & $25.2 *$ & $2.6^{*}$ & $25.2 *$ & $0.12 *$ \\
\hline $\mathrm{G}^{*} \mathrm{~L}$ & 26 & $0.8^{*}$ & $6242 *$ & $7.6^{*}$ & $7.1 *$ & $0.8^{*}$ & $3.1^{*}$ & $2.2 *$ & $6.7 *$ & $1.0 *$ & $3.4 *$ & $0.03 *$ \\
\hline $\mathrm{Y} * \mathrm{~L}$ & 2 & $3.1 *$ & $28513^{*}$ & $15.3 *$ & $1.8^{\mathrm{ns}}$ & $0.1^{\text {ns }}$ & $5.6^{*}$ & $5.9 *$ & $11.3^{*}$ & $5.8^{*}$ & $3.8^{*}$ & $0.04 *$ \\
\hline$G * Y * L$ & 26 & $0.5^{*}$ & $4790^{\mathrm{ns}}$ & $6.8^{*}$ & $7.7^{*}$ & $0.8^{*}$ & $4.3^{*}$ & $1.6^{*}$ & $5.6^{*}$ & $0.8^{*}$ & $3.9 *$ & $0.03 *$ \\
\hline Error & 84 & $0.0^{\mathrm{ns}}$ & $299^{\mathrm{ns}}$ & $0.5^{\mathrm{ns}}$ & $0.8^{\mathrm{ns}}$ & $0.3^{\mathrm{ns}}$ & $0.4^{\mathrm{ns}}$ & $0.3^{\mathrm{ns}}$ & $0.4^{\mathrm{ns}}$ & $0.1^{\mathrm{ns}}$ & $0.3^{\mathrm{ns}}$ & $0.00^{\mathrm{ns}}$ \\
\hline
\end{tabular}

${ }^{\text {a }} \mathrm{P}$ - crude protein, TEP - total extracted proteins, AG - albumins and globulins,

GLI - gliadins, GLU - glutenins, HMW - high molecular weight glutenin subunits,

LMW - low molecular weight glutenin subunits, GLI/GLU - gliadins/glutenins ratio

*significant at $\mathrm{P}<0.05$

Table 3. Cultivar and environmental effect on wheat proteins distribution

\begin{tabular}{|c|c|c|c|c|c|c|c|c|c|c|c|}
\hline & \multirow[b]{2}{*}{$\mathrm{P}^{\mathrm{a}}(\%)$} & \multirow[b]{2}{*}{$\begin{array}{c}\text { TEP } \\
(\mathbf{A U})^{\mathbf{b}}\end{array}$} & \multirow[b]{2}{*}{$\begin{array}{l}\mathbf{A G} \\
(\%)\end{array}$} & \multicolumn{4}{|c|}{ GLI (\%) } & \multicolumn{3}{|c|}{ GLU (\%) } & \multirow{2}{*}{$\begin{array}{l}\text { GLI/ } \\
\text { GLU }\end{array}$} \\
\hline & & & & Total & $\omega-$ & $\alpha-$ & $\gamma-$ & Total & HMW & LMW & \\
\hline \multicolumn{12}{|l|}{ Genotype } \\
\hline Srpanjka & 12.98 & 822 & 14.70 & 52.12 & 3.52 & 27.93 & 20.66 & 33.18 & 8.89 & 24.29 & 1.59 \\
\hline Žitarka & 13.92 & 821 & 13.53 & 56.64 & 3.67 & 30.11 & 22.85 & 29.83 & 8.42 & 21.41 & 1.91 \\
\hline Divana & 16.08 & 1012 & 12.21 & 53.21 & 3.80 & 28.53 & 20.80 & 34.58 & 10.81 & 23.83 & 1.55 \\
\hline Aida & 13.15 & 804 & 19.76 & 51.03 & 6.26 & 26.16 & 18.60 & 29.22 & 8.94 & 20.28 & 1.75 \\
\hline Felix & 13.03 & 835 & 16.15 & 50.98 & 3.26 & 27.88 & 19.84 & 32.87 & 8.69 & 24.18 & 1.55 \\
\hline Zlata & 12.75 & 754 & 14.65 & 48.71 & 3.09 & 24.55 & 21.07 & 36.64 & 9.01 & 27.62 & 1.35 \\
\hline Ilirija & 13.33 & 867 & 14.70 & 51.11 & 3.57 & 24.36 & 23.18 & 34.19 & 9.31 & 24.88 & 1.50 \\
\hline Sana & 12.65 & 773 & 16.30 & 56.48 & 3.47 & 24.42 & 28.60 & 27.22 & 6.03 & 21.19 & 2.09 \\
\hline Seka & 12.73 & 804 & 17.10 & 50.10 & 3.15 & 25.98 & 20.97 & 32.81 & 9.10 & 23.71 & 1.53 \\
\hline Renata & 13.93 & 864 & 15.88 & 50.79 & 2.97 & 27.06 & 20.75 & 33.33 & 9.00 & 24.33 & 1.53 \\
\hline Golubica & 14.27 & 902 & 13.31 & 54.82 & 3.63 & 30.22 & 21.07 & 31.87 & 9.70 & 22.16 & 1.74 \\
\hline Soissons & 12.17 & 770 & 19.69 & 46.23 & 2.97 & 20.82 & 22.44 & 34.08 & 8.96 & 25.12 & 1.36 \\
\hline Olimpija & 15.72 & 1075 & 13.25 & 50.40 & 3.72 & 28.11 & 18.57 & 36.35 & 8.74 & 27.62 & 1.40 \\
\hline Vulkan & 13.42 & 837 & 14.62 & 53.67 & 3.89 & 26.11 & 23.67 & 31.71 & 7.57 & 24.14 & 1.71 \\
\hline $\mathrm{LSD}_{0.05}$ & 0.05 & 14.05 & 0.58 & 0.72 & 0.46 & 0.50 & 0.43 & 0.53 & 0.25 & 0.44 & 0.05 \\
\hline \multicolumn{12}{|l|}{ Year } \\
\hline 2009 & 12.91 & 817 & 15.82 & 50.95 & 3.53 & 26.16 & 21.25 & 33.22 & 8.43 & 24.80 & 1.56 \\
\hline 2010 & 14.25 & 888 & 15.01 & 52.80 & 3.75 & 27.02 & 22.05 & 32.18 & 9.16 & 23.02 & 1.66 \\
\hline $\mathrm{LSD}_{0.05}$ & 0.02 & 5.30 & 0.22 & 0.27 & 0.17 & 0.19 & 0.16 & 0.20 & 0.09 & 0.17 & 0.02 \\
\hline \multicolumn{12}{|l|}{ Location } \\
\hline Osijek & 14.65 & 938 & 14.83 & 52.53 & 4.05 & 27.64 & 20.83 & 32.64 & 9.15 & 23.50 & 1.63 \\
\hline Tovarnik & 13.23 & 835 & 15.54 & 52.00 & 3.52 & 26.37 & 22.13 & 32.46 & 8.47 & 23.98 & 1.62 \\
\hline Požega & 12.86 & 786 & 15.88 & 51.10 & 3.35 & 25.76 & 21.99 & 33.02 & 8.77 & 24.25 & 1.58 \\
\hline $\mathrm{LSD}_{0.05}$ & 0.03 & 6.50 & 0.27 & 0.33 & 0.21 & 0.23 & 0.20 & 0.24 & 0.12 & 0.20 & 0.02 \\
\hline Means & 13.58 & 853 & 15.42 & 51.88 & 3.64 & 26.59 & 21.65 & 32.70 & 8.80 & 23.91 & 1.61 \\
\hline
\end{tabular}


On the average, AG accounting for $15.42 \%$ of the TEP, while $\alpha-(26.59 \%)$ and $\gamma-(21.65 \%)$ GLI and LMW $(23.91 \%)$ constitute a major part of TEP. $\omega$ - GLI $(3.64 \%)$ and HMW $(8.80 \%)$ were minor components of TEP (Table 2) in accordance with Wieser et al. (1998), Dupont et al. 2003. The P and TEP content varied between 12.17 $\%$ and $16.08 \%$ and $754 \mathrm{AU}$ and 1075 AU, respectively. The results of the linear correlation analyses $(\mathrm{P}<0.05)$ carried out on the proteins data showed that $\mathrm{P}$ and TEP content were highly significantly correlated $(r=0.914)$ (Figure 1) similar to Wiser et al. (1998), Horvat et al. (2006) and Tsilo et al. (2010). P and TEP were significantly negatively correlated with $A G$ and positively with GLI components and HMW. Among P and TEP and total GLU, LMW and GLI/GLU ratio did not find any significant correlation (Table 4) which indicates that these parameters are more under genetic control. In 2010, an extremely rainy year, there was noticed a statistically significant higher proportion of $\mathrm{P}$ and TEP as compared to year 2009 (12.91\% and 14.25\% and $817 \mathrm{AU}$ and $888 \mathrm{AU}$, respectively), as well as increasing of all GLI components and HMW.

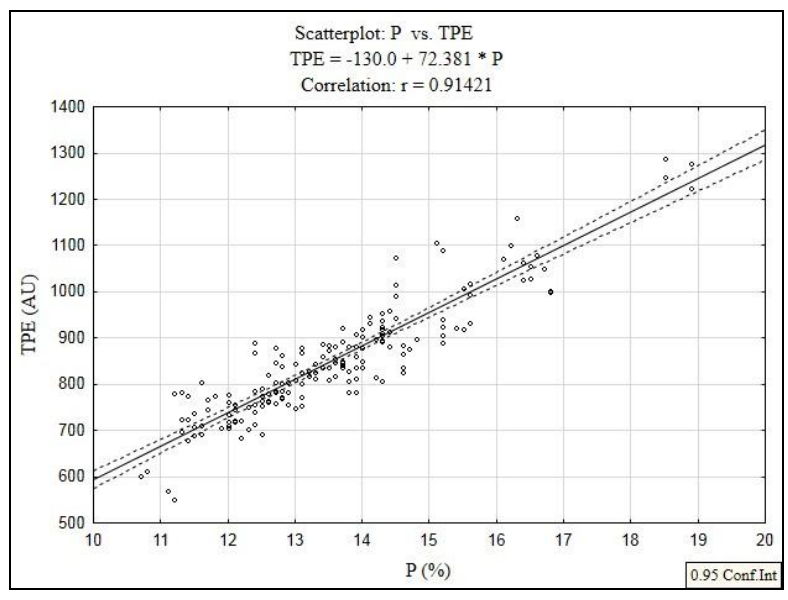

Figure 1. Relationship between $\mathrm{P}-$ crude protein content of grains and TEP - total extracted proteins

Table 4. Linear correlations between wheat protein components

\begin{tabular}{cccccccccc}
\hline \multirow{2}{*}{ Components } & \multirow{2}{*}{ AG } & Total & $\boldsymbol{\omega}-$ & $\boldsymbol{\alpha}-$ & $\boldsymbol{\gamma}-$ & Total & HMW & LMW & \multirow{2}{*}{ GLI/GLU } \\
\cline { 3 - 9 } & $-0.49^{*}$ & $0.33^{*}$ & $0.26^{*}$ & $0.57^{*}$ & $-0.28^{*}$ & $0.07^{\mathrm{ns}}$ & $0.45^{*}$ & $-0.12^{\mathrm{ns}}$ & $0.09^{\mathrm{ns}}$ \\
$\mathrm{P}^{\mathrm{a}}$ & $-0.37^{*}$ & $0.21^{*}$ & $0.28^{*}$ & $0.49^{*}$ & $-0.38^{*}$ & $0.11^{\mathrm{ns}}$ & $0.39^{*}$ & $-0.06^{\mathrm{ns}}$ & $-0.00^{\mathrm{ns}}$ \\
\hline $\mathrm{TEP}$ & & &
\end{tabular}

${ }^{a} \mathrm{P}$ - crude protein (\%), TEP - total extracted proteins, $\mathrm{AG}$ - albumins and globulins,

GLI - gliadins, GLU - glutenins, HMW - high molecular weight glutenin subunits,

LMW - low molecular weight glutenin subunits, GLI/GLU - gliadins/glutenins ratio

*significant at $\mathrm{P}<0.05$

The proportion of the AG, total GLU and LMW were significantly reduced. Generally, in Croatia in year 2010 yield, test weight and thousand grain weight of wheat were reduced by $20 \%-50 \%$. Many authors noticed that under such extreme climatic conditions a significant yield decrease leads to an increase in protein to starch ratio and vice versa (Qury et al., 2003; Triboi et al., 2006; Drezner et al., 2007). As a result of quantitative changes in proteins distribution in 2010 , the GLI/GLU ratio was increased in comparison to 2009 (1.66 and 1.56, respectively) (Table 3). PCA and factor analysis are the most widely used statistical methods to reduce the number of dimensions in data analysis and to investigate multiple intercorrelations between variables (Kurtanjek et al. 2008). Comparing cultivars, a several groups of related protein attributes were separated (Figure 2). Cv. Divana as Croatian standard for the highest quality has a distinct position on Figure 2 due to the highest P (16.08\%) and HMW (10.81\%) and the lowest AG (12.21\%). In our previous studies this cultivar was also characterized by the highest $\mathrm{P}$ and HMW proportion (Horvat et al., 2006, 2013). Cultivar Olimpija, which is also characterized by excellent bread-making properties, is more distant than $\mathrm{cv}$. Divana due to a significantly lower proportion of HMW $(8.74 \%)$ and lower GLI/GLU ratio (1.40). A lower GLI/GLU ratio is also characteristic of the cultivars Zlata and Soissons located on the opposite side to Olimpija. These cultivars have significantly lower proportion of $\mathrm{P}$, TEP, $\omega$ - and $\alpha$ - GLI. Croatian high yielding cultivar Sana is positioned on the opposite side due to the lowest HMW proportion $(6.03 \%)$ and total GLU $(27.22 \%)$ and the highest $\gamma$ - GLI (28.06 \%) and GLI/GLU ratio (2.09). In our previous studies this cultivar was also characterized by a lower proportion of HMW and weaker dough rheological properties (Horvat et al., 2006, 2013).

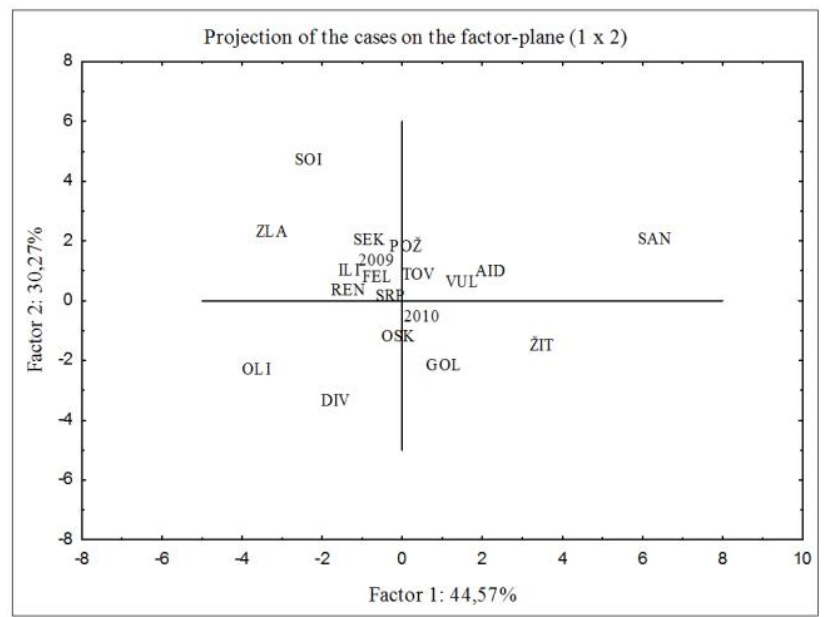

Figure 2. Projections of wheat cultivars onto the first two principal components considering mean values of protein components obtained under different environments. SRP Srpanjka, ŽIT - Žitarka, DIV - Divana, AID - Aida, FEL Felix, ZLA - Zlata, ILI - Ilirija, $\quad$ SAN - Sana, SEK Seka, REN - Renata, GOL - Golubica, SOI - Soissons, OLI Olimpija, VUL - Vulkan, Locations: OSK - Osijek, TOV Tovarnik, POŽ - Požega, Years: 2009 and 2010. 
Cultivar Žitarka with medium bread-making properties, has an isolated position due to the highest proportion of total GLI $(56.64 \%), \alpha$ - GLI $(30.11 \%)$ and a lower proportion of all GLU components. On Figure 2 it is clearly apparent that the distinction between analysed years as well as more similarity between locations Pozega and Tovarnik in comparison to the location Osijek.

\section{CONCLUSIONS}

Significant differences depending on cultivars, environments and their interactions were found among protein components of wheat grain. Considering the significant impact of grain proteins on the wheat breadmaking quality, cultivar classification by protein significantly contributes to the improvement of breeding program towards creation of high quality cultivars.

\section{ACKNOWLEDGMENTS}

This research was supported by the Ministry of Science, Education and Sport of the Republic of Croatia within the project "The development of new germplasm in breeding of quantitative wheat traits" (No. 073-07307180598).

\section{LITERATURE CITED}

Anderson, O.D., F. Bekes and R. D'Ovidio. 2011. Effects of specific domains of high-molecular-weight glutenin subunits on dough properties by an in vitro assay. J. Cereal Sci. 54:280-287.

Drezner, G., K. Dvojkovic, D. Horvat, D. Novoselovic, A. Lalic, D. Babic and J. Kovacevic. 2006. Grain Yield and Quality of Winter Wheat Genotypes in Different Environments. Cereal Res. Commun. 34:457-460.

Dupont, F.M. and S.B. Altenbach. 2003. Molecular and biochemical impacts of environmental factors on wheat grain development and protein synthesis. J. Cereal Sci. 38:133146.

Erekul, O., K.P. Gotz and T. Gurbuz. 2012. Effect of supplemental irrigation on yield and bread-making quality of wheat (Triticum aestivum L.) varieties under the mediterranean climatical conditions. Turk. J. Field Crops. 17:78-86.

Gao, L.Y., A.L. Wang, X.H. Li, K. Dong, K. Wang, R. Appels, W.J. Ma and Y.M. Yan. 2009. Wheat quality related differential expressions of albumins and globulins revealed by two-dimensional difference gel electrophoresis (2-D DIGE). J. Proteomics. 73:279-296.

Haiying, T., M.A. Jianjun, L. Chunlin, Y. Wei, Y. Mingkui and W. Bujun. 2012. Distribution of protein components of wheat from different regions. African J. Biotechnol. 11:10568-10574.
Horvat, D., Z. Jurković, G. Drezner, G. Šimić, D. Novoselović and K. Dvojković. 2006. Influence of gluten proteins on technological properties of Croatian wheat cultivars. Cereal Res. Commun. 34:1177-1184.

Horvat, D., N. Đukić, D. Magdić, J. Mastilović, G. Šimić, A. Torbica and D. Živančev. 2013. Characterization of bread wheat cultivars (Triticum aestivum L.) by glutenin proteins. Cereal Res. Commun. 41:133-140

Kurtanjek, Ž., D. Horvat, D. Magdić and G. Drezner. 2008. Factor analysis and modelling for rapid quality assessment of Croatian wheat cultivars with different gluten characteristics. Food Technol. Biotech. 46:270-277.

Osipova, S.V., M.D. Permyakova and A.V. Permyakov. 2012. Role of non-prolamin proteins and low molecular weight redox agents in protein folding and polymerization in wheat grains and influence on baking quality parameters. J. Agric. Food Chem. 60:12065-12073.

Pena, E., A. Bernardo, C. Soler and N. Jouve. 2005. Relationship between common wheat (Tritucum aestivum L.) gluten proteins and dough rheological properties - Gluten proteins and rheological properties in wheat. Euphytica. 143:169-177.

Qury, F.X. and C. Godin. 2007. Yield and grain protein concentration in bread wheat: how to use the negative relationship between the two characters to identify favourable genotypes? Euphytica. 157:45-57.

Shewry, P.R., A.S. Tatham and N.G. Halford. 2001. Nutritional control of storage protein synthesis in developing grain of wheat and barley. Plant Growth Regulation 34:105-111.

Tang, J.W., J.J. Liu, P.P. Zhang, Y. Zhang, Y.G. Xiao, Y.Y. Qu, Y. Zhang and Z.H. He. 2008. Effects of gluten protein fractions on dough property and products quality in common wheat. Sci. Agric. Sinica. 41:2937-2946.

STATISTICA Data Analysis Software System, version 8.0, Statsoft, Inc., Tulsa, OK, USA Torbica, A., M. Antov, J. Mastilovic and D. Knezevic. 2007. The influence of changes in gluten complex structure on technological quality of wheat (Triticum aestivum L.). Food Res. Int. 40:1038-1045.

Triboi, E., P. Martre, C. Girousse, C. Ravel and A.M. TriboiBlondel. 2006. Unravelling environmental and genetic relationship between grain yield and nitrogen concentration for wheat. Eur. J. Agron. 25:108-118

Tsilo, T.J., J.B. Ohm, G.A. Hareland and J.A. Anderson. 2010. Association of Size-Exclusion HPLC of Endosperm Proteins with Dough Mixing and Breadmaking Characteristics in a Recombinant Inbred Population of Hard Red Spring Wheat. Cereal Chem. 87:104-111.

Wieser, H., S. Antes and W. Selmeier. 1998. Quantitative determination of gluten protein types in wheat flour by reverse-phase high-performance liquid chromatography. Cereal Chem. 75:644-650.

Wieser, H. and R. Kieffer. 2001. Correlations of the amount of gluten protein types to the technological properties of wheat flours determined on a micro-scale. J. Cereal Sci. 34:19-27. 